\title{
Plant Bugs Predators (Hemiptera: Heteroptera: Miridae) with References to Arthropods and Fungi in Brazil
}

\author{
BÁRBARA C.F. NOGUEIRA ${ }^{1}$, PAULO S.F. FERREIRA ${ }^{1}$, LÍVIA A. COELHO ${ }^{2}$, \\ DAVID S. MARTINS ${ }^{2}$ and BÁRBARA D. BARCELLOS ${ }^{1}$
}

${ }^{1}$ Universidade Federal de Viçosa, Departamento de Biologia Animal, Avenida Peter Henry Rolfs, s/n, 36570-000 Viçosa, MG, Brazil

${ }^{2}$ Universidade Federal de Viçosa, Departamento de Entomologia, Avenida Peter Henry Rolfs, s/n, 36570-000 Viçosa, MG, Brazil

Manuscript received on November 12, 2018; accepted for publication on January 31, 2019

\begin{abstract}
How to cite: NOGUEIRA BCF, FERREIRA PSF, COELHO LA, MARTINS DS AND BARCELLOS BD. 2019. Plant Bugs Predators (Hemiptera: Heteroptera: Miridae) with References to Arthropods and Fungi in Brazil. An Acad Bras Cienc 91: e20181194. DOI 10.1590/0001-3765201920181194.
\end{abstract}

\begin{abstract}
The present study demonstrates 30 plant bugs species associated with 50 records of prey and six records of mycophagy for Brazil. The data were compiled from Schuh's Catalog, the literature, specimens deposited in entomology museums and exemplars from different regions of Brazil sent for identification. Some of the data from the literature used did not presented complete information. This study aims to increase the knowledge of the relationships among plant bugs, prey and fungi and emphasize those species with potential for biological control strategies and pest integrated management.
\end{abstract}

Key words: arthropod, fungi, insect, prey.

\section{INTRODUCTION}

Plant bugs have a very great ecological importance due to the high diversity and occurrence in many zoogeographic regions (Cassis and Schuh 2012). They have a wide feeding behavior varying as phytophagous, predators, saprophagous and fungivorous (Henry and Wheeler 1988, Wheeler 2001). This happens because their mouthparts allow the exploitation of a great variety of food source (Schuh and Slater 1995, Grimaldi and Engel 2005, Gullan 2014), due to the presence of digestive enzymes (Boyd et al. 2002) and other chemical substances released from the salivary

Correspondence to: Bárbara Cristina Félix Nogueira

E-mail: barbaracfn28@gmail.com

ORCid: https://orcid.org/0000-0002-8440-4525 glands (Wheeler 2001), which allow the prey immobilization (Cohen 1996).

Plant bugs are among the most important insect groups in agriculture because they can act either as plague for crops as well as biological control agents (Henry and Wheeler 1988, Wheeler 2001). Their predation habit is not commonly recognized as they do not have the morphological structures used to capture prey. However, there are observations in nature about plant bug predating eggs, immature and adult forms of arthropods, and their life cycles may synchronize with those of prey (Schuh and Slater 1995, Wheeler 2000, 2001, Shockley and Murray 2006). In addition, records of plant bugs feeding on dead and disabled invertebrates have been reported (Wheeler 2001). 
Given the ecological and economic importance of plant bugs, the aim of this study is to increase the knowledge about these arthropods in associations with prey and fungi in Brazil. Additionally, the study intends to emphasize potential species for biological control.

\section{MATERIALS AND METHODS}

All data came from On-line Systematic Catalog of Plant Bugs (Schuh 2002-2013), Taxonomic Catalog of the Brazilian Fauna (TCBF), specialized literature, information from labels of specimens deposited in the Regional Museum of Entomology of the Universidade Federal de Viçosa, Minas Gerais, Brazil (UFVB), and the National Museum of the Universidade Federal do Rio de Janeiro, Rio de Janeiro, Brazil (MNRJ). Some of the data from the literature used did not presented complete information. The study also included data from many specimens from several regions of Brazil sent for identification to UFVB.

The data were compiled in the Microsoft Excel software relating the plant bug species with prey and mycophagy, the associated plant where the predator and prey were found, and the source of literature.

\section{RESULTS AND DISCUSSION}

Up to date, there was no information grouped available about the potential occurrences of predation by plant bugs in Brazil. In this study we found 30 species of plant bugs with potential prey and fungi associations were recorded for Brazil, in all 56 associations, 50 of which were records of prey, six records of mycophagy, of which 18 were associated with plant material (Table I).

The plant bug Hyaliodocoris insignis was observed preying on Duponchelia fovealis (Lepidoptera: Crambidae) (Zawadneak et al. 2016). This Lepidoptera has many registers attacking strawberry (Fragaria x ananassa) crops in many regions of the planet (Bonsignore and Vacante 2010). D. fovealis was first recorded in Brazil in 2010 causing serious damages in strawberry (Zawadneak et al. 2016). Until now, there is no record of this plant bug attacking strawberry crops in Brazil. Nevertheless, further studies on the potential of this plant bug as a biological control agent regarding this pest are necessary.

The plant bugs Engytatus modestus and Engytatus varians have records of predation on Bemisia tabaci (Hemiptera: Aleyrodidae) (Gerling et al. 2001). This Aleyrodidae has a vast geographic distribution and was considered pest in more than 500 agricultural crop species around the world (Cock 1993).

E. modestus is a predator of Dysmicoccus brevipes (Hemiptera: Pseudococcidae) (Wheeler 2001), a pantropical pest of pineapple (Silva et al. 1968, Scardini 1983, Mau and Kessing 1992). This plant bug is a potential agent of biological control of Liriomyza trifolii (Diptera: Agromyzidae), which is a serious pest of a great number of host plants, including ornamental species (Stegmaier 1966, Spencer 1973).

The plant bug Campyloneuropsis cincticornis is a predator of Gratiana spadicea (Klug) (Coleoptera: Chrysomelidae), a monophagous species that feeds on Solanum sisymbriifolium, an invasive plant of pasture and other important crops (Groth 1989, Mentz and Oliveira 2004).

Some species of plant bugs in Brazil are recorded as family Ortheziidae (Hemiptera: Sternorrhyncha) predators (Table I): Ambracius dufouri (Ferreira 1998, Wheeler 2001), Ofellus guaranianus (Wheeler 2001) and Adhyalochloria inermis preying on Fuchsia regia (Museu Regional de Entomologia da Universidade Federal de Viçosa). Species of the Ortheziidae, known as scales, usually constitute serious pests associated with plants of economic importance. They occur in most parts of the world mainly in the Neotropics and Nearctic regions (Nascimento et al. 1993). 
TABLE I

Plant bugs predators and mycophagous species in Brazil.

\begin{tabular}{lccc}
\multicolumn{1}{c}{ Miridae } & Prey/mycophagy & Associated Plant & Reference \\
\hline $\begin{array}{l}\text { Adhyalochloria inermis } \\
\text { (Carvalho, 1985) }\end{array}$ & Hemiptera Ortheziidae & $\begin{array}{l}\text { Fuchsia regia } \\
\text { (Onagraceae) }\end{array}$ & Unpublished data
\end{tabular}

Ambracius dufouri Stal, 1860

Campyloneuropsis cincticornis (Stal, 1860)

Campyloneuropsis infumatus (Carvalho, 1947)
Hemiptera Ortheziidae

Gratiana spadicea (Coleoptera: Chrysomelidae)

Tuta absoluta (Lepidoptera: Gelechiidae) (eggs and larva)

Tuta absoluta (Lepidoptera: Gelechiidae)

Heliothis virescens (Lepidoptera: Noctuidae)

Alabama argilacea (Lepidoptera: Noctuidae) (eggs and larva)

Ceratocapsus mariliensis Carvalho \& Fontes, 1983

Cylapocoris pilosulus Knight, 1930

Cylapocoris tiquiensis Carvalho, 1954

Cylapus citus Bergroth, 1922

Cylapus ruficeps Bergroth, 1922

Engytatus modestus (Distant, 1893)
Alabama argilacea (Lepidoptera: Noctuidae) (eggs and larva)

Heliothis virescens (Lepidoptera: Noctuidae)

Auricularia Fungus

Auricularia Fungus

Pirenomiceto Fungus

Pirenomiceto Fungus

Liriomyza trifolii (Diptera: Agromyzidae)

Heliothentines (Lepidoptera: Noctuidae). (larva and pulp)

Pieris rapae (Lepidoptera:

Pieridae) (larva and pulp)

Dysmicoccus brevipes (Hemiptera: Pseudococcidae)

Tupiocoris notatus (Hemiptera: Miridae) (nimph and adult)
Ferreira (1998), Wheeler (2001)

Wheeler (2001)
Solanum lycopersicum

(Solanaceae)

Martínez et al. (2014)

Van Lenteren et al. (2016)

Wheeler (2001)

Gossypium L. (Malvaceae)

Gossypium L.

(Malvaceae)

Wheeler (2001)
Carvalho (1954)

Carvalho (1954)

Schuh (1976), Wheeler (2001)

Schuh (1976), Wheeler (2001)

Unpublished data

Wheeler (2001)
Ananas comosus

(Bromeliaceae)

Nicotiana tabacum (Solanaceae) 
TABLE I (continuation).

\begin{tabular}{|c|c|c|c|}
\hline Miridae & Prey/mycophagy & Associated Plant & Reference \\
\hline & Aphids & $\begin{array}{l}\text { Solanum lycopersicum } \\
\text { (Solanaceae) }\end{array}$ & \\
\hline & $\begin{array}{c}\text { Myzus persicae (Hemiptera: } \\
\text { Aphidae) }\end{array}$ & & \\
\hline & $\begin{array}{c}\text { Bemisia tabaci (Hemiptera: } \\
\text { Aleyrodidae) }\end{array}$ & & Gerling et al. (2001) \\
\hline \multirow[t]{4}{*}{$\begin{array}{l}\text { Engytatus varians (Distant, } \\
\text { 1884) }\end{array}$} & $\begin{array}{c}\text { Bemisia tabaci (Hemiptera: } \\
\text { Aleyrodidae) }\end{array}$ & & Wheeler (2001) \\
\hline & $\begin{array}{l}\text { Heliothis virescens (Lepidoptera: } \\
\text { Noctuidae) (initial stages) }\end{array}$ & & Martínez et al. (2014) \\
\hline & $\begin{array}{l}\text { Tuta absoluta (Lepidoptera: } \\
\text { Gelechiidae) (eggs and larva) }\end{array}$ & & \\
\hline & $\begin{array}{l}\text { Tuta absoluta (Lepidoptera: } \\
\text { Gelechiidae)*** }\end{array}$ & & $\begin{array}{l}\text { Van Lenteren et al. } \\
\qquad(2016)\end{array}$ \\
\hline \multirow[t]{4}{*}{ Fulvius anthocoroides Stal, 1862} & Hemiptera Aradidae & & Alayo (1974) \\
\hline & Coleoptera & & \\
\hline & Miriapoda & & \\
\hline & Fungus & Tree debris & Schuh (1976) \\
\hline $\begin{array}{l}\text { Fulvius quadristillatus (Stal, } \\
\text { 1860) }\end{array}$ & Auricularia Fungus & Tree debris & $\begin{array}{l}\text { Maes and Carvalho } \\
\text { (1989) }\end{array}$ \\
\hline \multirow[t]{3}{*}{$\begin{array}{l}\text { Hyaliodes beckeri Carvalho, } \\
1953\end{array}$} & $\begin{array}{c}\text { Chrysoperla externa (Neuroptera: } \\
\text { Chrysopidae) }\end{array}$ & & Wheeler (2001) \\
\hline & $\begin{array}{c}\text { Erinnyis ello (Lepidoptera: } \\
\text { Sphingidae) }\end{array}$ & $\begin{array}{l}\text { Manihot esculenta } \\
\text { (Euphorbiaceae) }\end{array}$ & \\
\hline & $\begin{array}{c}\text { Vatiga illudens (Hemiptera: } \\
\text { Tingidae) }\end{array}$ & & Oliveira et al. (2002) \\
\hline $\begin{array}{l}\text { Hyaliodocoris insignis Carvalho, } \\
1976\end{array}$ & $\begin{array}{c}\text { Duponchelia fovealis } \\
\text { (Lepidoptera: Crambidae) }\end{array}$ & $\begin{array}{l}\text { Fragaria } \times \text { ananassa } \\
\quad(\text { Rosaceae })\end{array}$ & Zawadneak et al. (2016) \\
\hline \multirow[t]{2}{*}{$\begin{array}{l}\text { Macrolophus basicornis (Stal, } \\
\text { 1860) }\end{array}$} & $\begin{array}{c}\text { Tuta absoluta (Lepidoptera: } \\
\text { Gelechiidae)*** }\end{array}$ & & $\begin{array}{l}\text { Van Lenteren et al. } \\
\qquad(2016)\end{array}$ \\
\hline & $\begin{array}{c}\text { Tuta absoluta (Lepidoptera: } \\
\text { Gelechiidae) }\end{array}$ & $\begin{array}{l}\text { Solanum lycopersicum } \\
\text { (Solanaceae) }\end{array}$ & Martínez et al. (2014) \\
\hline \multirow[t]{3}{*}{$\begin{array}{l}\text { Macrolophus praeclarus } \\
\text { (Distant, 1884) }\end{array}$} & $\begin{array}{l}\text { Hymenoptera Formicidae } \\
\text { (weakened) }\end{array}$ & & Wheeler (2001) \\
\hline & Thysanoptera & & Unpublished data \\
\hline & Hemiptera Aleyrodidae & & \\
\hline
\end{tabular}


TABLE I (continuation).

\begin{tabular}{|c|c|c|c|}
\hline Miridae & Prey/mycophagy & Associated Plant & Reference \\
\hline $\begin{array}{l}\text { Ofellus guaranianus Carvalho, } \\
1985\end{array}$ & Hemiptera Ortheziidae & & Wheeler (2001) \\
\hline $\begin{array}{l}\text { Perissobasis heroni Ferreira \& } \\
\text { Coelho, } 2009\end{array}$ & Small arthropods & $\begin{array}{l}\text { Coffea arabica } \\
\text { (Rubiaceae) }\end{array}$ & Ferreira et al. (2009) \\
\hline $\begin{array}{l}\text { Peritropis saldaeformis Uhler, } \\
1891\end{array}$ & Small insects & & Unpublished data \\
\hline $\begin{array}{l}\text { Ranzovius clavicornis (Knight, } \\
\text { 1927) }\end{array}$ & $\begin{array}{c}\text { Anelosimus studiosus (Araneae: } \\
\text { Theridiidae) }\end{array}$ & & Henry (1984) \\
\hline \multirow[t]{2}{*}{$\begin{array}{l}\text { Ranzovius fennahi Carvalho, } \\
1954\end{array}$} & $\begin{array}{c}\text { Anelosimus studiosus (Araneae: } \\
\text { Theridiidae) }\end{array}$ & & Henry (1999) \\
\hline & $\begin{array}{c}\text { Anelosimus eximius (Araneae: } \\
\text { Theridiidae) (eggs) }\end{array}$ & & $\begin{array}{l}\text { Henry (1984), Maes and } \\
\text { Carvalho (1989) }\end{array}$ \\
\hline \multirow[t]{2}{*}{$\begin{array}{l}\text { Rhinacloa forticornis Reuter, } \\
1876\end{array}$} & $\begin{array}{l}\text { Heliothis virescens (Lepidoptera: } \\
\text { Noctuidae) (larva) }\end{array}$ & & Donnelly (2000) \\
\hline & $\begin{array}{l}\text { Lygus sp. (Hemiptera: Miridae) } \\
\text { (Do not occur in Brazil) } * * *\end{array}$ & & Wheeler (2001) \\
\hline $\begin{array}{l}\text { Sericophanes obscuricornis } \\
\text { Poppius, } 1921\end{array}$ & $\begin{array}{c}\text { Listronotus bonariensis } \\
\text { (Coleoptera: Curculionidae) }\end{array}$ & & Wheeler (2001) \\
\hline \multirow[t]{2}{*}{$\begin{array}{l}\text { Termatophylidea opaca } \\
\text { Carvalho, } 1955\end{array}$} & Thysanoptera & & Ferreira (1993) \\
\hline & $\begin{array}{c}\text { Cyrtotylus rubricatus (Hemiptera: } \\
\text { Miridae) }\end{array}$ & & \\
\hline \multirow[t]{2}{*}{ Thyttus parviceps (Reuter, 1890) } & $\begin{array}{l}\text { Perkinsiella saccharicida } \\
\text { (Hemiptera: Fulgoroidea) }\end{array}$ & & $\begin{array}{l}\text { Hernandez and Henry } \\
\text { (2010) }\end{array}$ \\
\hline & $\begin{array}{c}\text { Tagosodes orizicola (Hemiptera: } \\
\text { Delphacidae) (eggs) }\end{array}$ & Oryza sativa (Poaceae) & \\
\hline Trigonotylus tenuis Reuter, 1893 & Homoptera (unidentified) & Oryza sativa (Poaceae) & Unpublished data \\
\hline \multirow[t]{2}{*}{$\begin{array}{l}\text { Tupiocoris cucurbitaceus } \\
\text { (Spinola, 1852) }\end{array}$} & $\begin{array}{l}\text { Trialeurodes vaporariorum } \\
\text { (Hemiptera: Aleyrodidae) }\end{array}$ & $\begin{array}{l}\text { Solanum lycopersicum } \\
\text { (Solanaceae) }\end{array}$ & $\begin{array}{l}\text { López et al. (2012) } \\
\text { Sitotroga cerealella eggs } \\
\text { and a mix of both }\end{array}$ \\
\hline & Hemiptera Cicadellidae & & Wheeler (2001) \\
\hline Tytthus femoralis Henry, 2012 & $\begin{array}{l}\text { Perkinsiella spp. (Hemiptera: } \\
\text { Fulgoroidea) (eggs) }\end{array}$ & & Henry (2012) \\
\hline
\end{tabular}

*** captivity. 
Three species of plant bugs are recorded as predators of the Tuta absoluta (Lepidoptera: Gelechiidae) (Table I): Campyloneuropsis infumatus, preying on eggs and larvae found on tomato (Martínez et al. 2014, Van Lenteren et al. 2016); Engytatus varians, preying on eggs and larvae (Van Lenteren et al. 2016), and Macrolophus basicornis, preying in natural and laboratorial conditions (Martínez et al. 2014, Van Lenteren et al. 2016). T. absoluta is a neotropical Lepidoptera found in many countries of South America (Benavent et al. 1978, Souza et al. 1983, Larraín 1986, Cáceres 1992, IAN-JICA 1994). It is responsible for economic losses to Solanaceae crops due to decrease in production. Its common name, the tomato moth, is due to the damage it causes in the tomato (Solanum lycopersicum). The larvae of this Lepidoptera produce galleries in different parts of the plant (Benavent et al. 1978, Souza et al. 1983, Cáceres 1992).

Four species of plant bugs are cited as predators of Heliothis virescens (Lepidoptera: Noctuidae): Ceratocapsus dispersus (Wheeler 2001), Ceratocapsus mariliensis (Wheeler 2001), Engytatus varians (Martínez et al. 2014), and Rhinacloa forticornis (Donnelly 2000). $H$. virescens is considered a pest in the Americas (Fitt 1989, Moraes and Mescher 2005) associated with eight plant families (Yépez et al. 1990). It is known as "tobacco budworm" and is considered the main pest of the cotton crop as it attacks the cotton apple (Santos 2001).

The plant bug Hyaliodes beckeri was reported predating Chrysoperla externa (Neuroptera: Chrysopidae) (Wheeler 2001). Chrysopidae is an important family in biological control of arthropod pests in many cultures, such as orange crops (Nasca et al. 1983, Gravena et al. 1993). This can reinforce the hypothesis that predatory habit usually has a generalized way in the selection of prey.

Beside this, H. beckeri, is predator Erinnyis ello (Lepidoptera: Sphingidae) and Vatiga illudens
(Hemiptera: Tingidae) (Oliveira et al. 2002). E. ello is a native pest of manioc (Manihot esculenta). It is native from Brazil, but also occurs in other South American countries, presenting large geographic distribution due to its fly ability. $E$. ello, is a defoliator insect that consumes manioc leaves in the larval phase. It also feeds on over 35 plant species (Fazolin et al. 2007). In Brazil, it is commonly known as "Mandarová-da-mandioca" and is considered the most important pest of manioc crop. Another manioc crop pest that presents major importance is the $V$. illudens, which occurs in South and Central America and this pest is able to reduce up to 22 percent the production of manioc root (Fialho et al. 1994).

The plant bug Sericophanes obscuricornis is a Listronotus bonariensis (Coleoptera: Curculionidae) predator (Wheeler 2001). This Coleoptera is a species of weevil native from South America. The larval and adult stages of weevil are pests of grasses and cereals. In Brazil, wheat, ryegrass, rye, and corn are examples of crops affected by this pest (Gassen 1989).

Thyttus parviceps is the only plant bug Perkinsiella saccharicida (Hemiptera: Fulgoroidea) predator (Hernandez and Henry 2010). This Hemiptera is the vector of the Fiji disease virus to sugar cane (Egan et al. 1989).

The plant bug Tupiocoris cucurbitaceus is a predator of the Trialeurodes vaporariorum (Hemiptera: Aleyrodidae). This Hemiptera is known as "whitefly", a pest of many fruits and vegetables such as cucurbits, potatoes, tomatoes, and ornamental crops. It is often found in greenhouses and may cause damage by its feeding behavior, the honeydew, and the transmission of several plant viruses (Russell 1977, López et al. 2012).

The mycophagy is a common feeding behavior among insects that inhabit in remaining vegetables in contact with reproductive and vegetative parts of fungi (Martin 1979). In Brazil this behavior is 
presented by the species Cylapocoris pilosulus, $C$. tiquiensis, Cylapus citrus and C. ruficeps. Members of the subfamily Cylapinae, which lives in tree trunks containing fungi, are good examples of plant bugs that feeds on fungi (Leston 1961, Wheeler 2001). Furthermore, the mycophagy behavior of Cylapinae can be confirmed through the observation of fungi material found inside dissected specimens (Wheeler and Wheeler 1994).

In conclusion, this study increases the knowledge of the associations between species of Miridae and their food habits. In addition, the data and information presented in this study show the need for more biological and ecological studies on predator-prey relations and fungi associations, in order to explore the potential of some species of Miridae as biological control agents, as well as important resources for integrated pest management strategies.

\section{AUTHOR CONTRIBUTIONS}

BCFN: Article writing and contributed by searching bibliographical material referring to associations of Miridae in Brazil, organization of the data deposited in the UFVB and data processing. PSFF: Assistance to the entomological collection and identification; Elaboration, writing and revision of the manuscript. LAC and DSM: Assistance to the entomological collection; Bibliographic review research and revision of the manuscript. BDB: Bibliographic review research; Elaboration, writing and revision of the manuscript.

\section{REFERENCES}

ALAYO DP. 1974. Los Hemipteros de Cuba. Parte XIII. Familia Miridae. Torreia 32: 1-41.

BENAVENT J, KUEFFNER E AND VIGIANI A. 1978. Organizacióny planificación de la investigación para el desarrollo de un programa de control integrado de la polilla del tomate Scrobipalpula absoluta (Meyrick), Lepidoptera: Gelechiidae, en la República Argentina. Curso de Perfeccionamiento en Control Integrado de Plagas. Compendio, Tomo II. Buenos Aires, INTA, 16 p.
BONSIGNORE CP AND VACANTE V. 2010. Duponchelia fovealis Zeller. Une nuova emergenza per la fragola? Protezione delle colture 3: 40-43.

BOYD DW, COHEN AC AND ALVERSON DR. 2002. Digestive enzymes and stylet morphology of Deraeocoris nebulosus (Hemiptera: Miridae), a predacious plant bug. Ann Entomol Soc Am 95: 395-401.

CÁCERES S. 1992. La polilla del tomate en Corrientes. Biología y control. Estación Experimental Agropecuaria Bella Vista, INTA, 19 p.

CARVALHO JCM. 1954. Neotropical Miridae, LXXIV: Two New Genera of Cylapinae from Brazil (Hemiptera). Proc Iowa Acad Sci 61: 504-510.

CASSIS G AND SCHUH RT. 2012. Systematics, biodiversity, biogeography, and host associations of the Miridae (Insecta: Hemiptera: Heteroptera: Cimicomorpha). Annu Rev Entomol 57: 377-404.

COCK MJW. 1993. Bemisia tabaci: An update 1986-1992 on the whitefly with an annotated bibliography. CAB International Institute of Biological Control, Ascot, UK, p. 78.

COHEN AC. 1996. Plant feeding by predatory Heteroptera: Evolutionary and adaptational aspects of trophic switching. In: Alomar O and Wiedenmann RN (Eds), Zoophytophagous Heteroptera: implications for life history and integrated pest management. Thomas Say Publications in Entomology: Proceedings. Entomological Society of America, Lanham, Md., p. 1-17.

DONNELLY GP. 2000. Biology and host specificity of Rhinacloa callicrates Herring (Hemiptera: Miridae) and its introduction and establishment as a biological control agent of Parkinsonia aculeata L. (Caesalpiniaceae) in Australia. Austral Entomology 39: 89-94.

EGAN BT, RYAN CC AND FRANCKI RIB. 1989. Fiji disease. In: Ricaud C, Egan BT, Gillaspie AGJ and Hughes CG (Eds), Diseases of sugarcane: major diseases. Amsterdam: Elsevier, 399 p.

FAZOLIN M, ESTRELA JLV, FILHO MDC, SANTIAGO ACC AND FROTA FS. 2007. Manejo integrado de Mandavorá-da-Mandioca Erinnyis ello (L.) (Lepidoptera: Sphingidae): conceitos e experiências na região do Vale do Rio Juruá, Acre. EMBRAPA Acre, Documento 107, Rio Branco, $45 \mathrm{p}$.

FERREIRA PSF. 1993. Descrição do macho e primeiro registro para o Brasil de Termatophylidea opaca Carvalho (Heteroptera: Miridae: Termatophylini). An Soc Entomol Bras 22: 485-490.

FERREIRA PSF. 1998. The tribe Clivinematini: cladistic analysis, geographic distribution and biological considerations (Heteroptera: Miridae). Rev Bras Entomol 42: 53-57.

FERREIRA PSF, UCELI LF, COELHO LA AND PIROVANI VD. 2009. Description of a new species Perissobasis 
heroni (Hemiptera: Heteroptera: Deraeocorinae), found on Coffea arabica, and with key to Neotropical species of the genus. Zootaxa 58: 50-58.

FIALHO JF, OLIVEIRA MAS AND ALVES RT. 1994. Efeito do dano do percevejo-de-renda Vatiga illudens (Drake, 1922) sobre o rendimento da mandioca no Distrito Federal. In: Congresso Brasileiro de Mandioca, 8, Salvador. Resumos. Salvador: Sociedade Brasileira de Mandioca, $91 \mathrm{p}$.

FITT GP. 1989. The ecology of Heliothis species in relation to agroecosystems. Annu Rev Entomol 34: 17-52.

GASSEN DN. 1989. Insetos subterrâneos prejudiciais às culturas do Sul do Brasil. EMBRAPA-CNPT, Documento 13, Passo Fundo, 72 p.

GERLING D, ALOMAR Ò AND ARNÓ J. 2001. Biological control of Bemisia tabaci using predators and parasitoids. Crop Prot 20: 779-799.

GRAVENA S, YAMAMOTO PT AND FERNANDES OF. 1993. Biologia de Parlatoria cinerea (Hemiptera: Diaspididae) e predação por Chrysoperla externa (Neuroptera: Chrysopidae). Científica 21: 149-156.

GRIMALDI D AND ENGEL MS. 2005. Evolution of the Insects. Cambridge University Press: New York, 772 p.

GROTH D. 1989. Caracterização morfológica das sementes e plântulas de seis espécies invasoras do gênero Solanum L. Acta Bot Bras 3: 25-41.

GULLAN PJ AND CRANSTON PS. 2014. The Insects. An Outline of Entomology. $5^{\text {th }}$ ed., Wiley-Blackwell, 584 p.

HENRY TJ. 1984. Revision of the spider-commensal plant bug genus Ranzovius Distant (Heteroptera; Miridae). P Entomol Soc Wash. 86: 53-67.

HENRY TJ. 1999. The spider-commensal plant bug genus Ranzovius (Heteroptera: Miridae: Phylinae) revisited: three new species and a revised key, with the description of a new sister genus and phylogenetic analysis. Acta Societatis Zoologicae Bohemicae 63: 93-115.

HENRY TJ. 2012. Revision of the plant bug genus Tytthus (Hemiptera, Heteroptera, Miridae, phylinae). ZooKeys 220: 1-114.

HENRY TJ AND WHEELER AG. 1988. Family Miridae Hahn, 1833 (= Capsidae Burmeister, 1835). In: Henry TJ and Froeschner RC (Eds), Catalog of the Heteroptera, or True Bugs of Canada and the Continental United States. E J Brill: Leiden, p. 251-507.

HERNANDEZ LM AND HENRY TJ. 2010. The plant bugs, or Miridae (Hemiptera: Heteroptera), of Cuba. Pensoft Series Faunistica 92: 1-212.

IAN-JICA - INSTITUTO AGRONÓMICO NACIONAL \& AGENCIA DE COOPERACIÓN INTERNACIONAL DE JAPÓN. 1994. Control integrado de la palomilla del tomate Scrobipalpula absoluta (Meyrick, 1917). Caacupé, Paraguay, JICA, 173 p.
LARRAÍN P. 1986. Eficacia de insecticidas y frecuencia de aplicación basada en niveles poblacionales críticos de Scrobipalpula absoluta (Meyrick), en tomates. Agricultura Técnica 46: 329-333.

LESTON D. 1961. Testis follicle number and the higher systematic of Miridae (Hemiptera: Heteroptera). P Zool Soc Lond 137: 89-106.

LÓPEZ SN, ROJAS FA, VELÁSQUEZ VV AND CAGNOTTI C. 2012. Biology of Tupiocoris cucurbitaceus (Hemiptera: Miridae), a predator of the greenhouse whitefly Trialeurodes vaporariorum (Hemiptera: Aleyrodidae) in tomato crops in Argentina. Biocontrol Sci Techn 22: 11071117.

MAES JM AND CARVALHO JCM. 1989. Catalogo de los Miridae (Heteroptera) de Nicarágua. Rev Nicar Entomol 6: 7-36.

MARTIN MM. 1979. Biochemical implications of insect mycophagy. Biol Rev 54: 1-21.

MARTÍNEZ MA, DUARTE L, BAÑOS HL, RIVAS A AND SÁNCHEZ A. 2014. Predatory mirids (Hemiptera: Heteroptera: Miridae) in tomato and tobacco in Cuba. Rer Protección Veg 29: 204-207.

MAU RFL AND KESSING JLM. 1992. Dysmicoccus brevipes (Cockerell). Available at: www.extento.hawaii.edu/kbase/ crop/Type/d_brevip.htm. Accessed in October 18, 2017.

MENTZ LA AND OLIVEIRA PL. 2004. Solanum (Solanaceae) na região sul do Brasil. Pesquisas/ Instituto Anchietano de Pesquisas, São Leopoldo, Unisinos, 327 p.

MORAES CM AND MESCHER MC. 2005. Intrinsic competition between larval parasitoids with different degrees of host specificity. Ecol Entomol 30: 564-570.

NASCAAJ, FENÁNDEZ RV, HERRERO AJ AND MANZUR BE. 1983. Incidencia de los tratamientos químicos para controle de moscas de los frutos (Trypetidae) sobre crisópidos y hemeróbidos (Neuroptera) em plantas cítricas. Cirpon Rev Invest 1: 47-73.

NASCIMENTO FN, PERRUSO JC AND CASSINO PCR. 1993. Novos hospedeiros de Orthezia praelonga Douglas, 1891 (Homoptera:Ortheziidae). An Soc Entomol Bras 22: 213-215.

OLIVEIRA MAS, FIALHO JF AND ICUMA IV. 2002. Ocorrência do mirídeo Hyaliodes beckeri predando o percevejo da renda Vatiga illudens em mandioca no Distrito Federal. Embrapa Comunicado Técnico 1-2.

RUSSELL LM. 1977. Hosts and distribution of the greenhouse whitefly, Trialeurodes vaporariorum (Westwood), (Hemiptera: Homoptera: Aleyrodidae) Vegetables, ornamentals. International Information System for the Agricultural Science and Technology 25: 449-458.

SANTOS WJ. 2001. Evolução das Pragas do Algodoeiro no Cerrado. Correio Agrícola 1: 20-27.

SCARDINI DMB. 1983. Eficiência de Inseticidas no Controle da Cochonilha do Abacaxizeiro no Espírito 
Santo EMCAPA, Pesquisa em Andamento, 15. EMCAPA: Cariacica 15: 1-4.

SCHUH RT. 1976. Pretarsal structure in the Miridae (Hemiptera) with a cladistic analysis of relationships within the family. Am Mus Novit 36: 1-39.

SCHUH RT. 2002-2013. On-line Systematic Catalog of Plant Bugs (Insecta: Heteroptera: Miridae). Available at: http:// research.amnh.org/pbi/catalog/.

SCHUH RT AND SLATER JA. 1995. True Bugs of the World (Hemiptera: Heteroptera): Classification and Natural History. Cornell University Press 89: 609-610.

SHOCKLEY FW AND MURRAY KL. 2006. Discovery of a parasitoid and a predator of bat flies (Diptera: Streblidae) at La Selva, Costa Rica. Biotropica 38: 789-790.

SILVA AGA, GONÇALVES CR, GALVÃO DM, GONÇALVES AJL, GOMES J, SILVA MN AND SIMONI L. 1968. Quarto catálogo dos insetos que vivem nas plantas do Brasil seus parasitos e predadores. Parte II, $1^{\circ}$ Tomo, Rio de Janeiro, Ministério da Agricultura.

SOUZA JC, REIS PR, NACIF AP, GOMES JM AND SALGADO LO. 1983. Controle da traça-do-tomateiro. Histórico, reconhecimento, biología, prejuízos e controle. Belo Horizonte, Empresa de Pesquisa Agropecuária de Minas Gerais, 15 p.

SPENCER KA. 1973. Agromyzidae (Diptera) of economic importance. Series entomologica, 9, The Hague: Netherlands, $418 \mathrm{p}$.
STEGMAIER CEJ. 1966. Host plants and parasites of Liriomyza trifolii in Florida (Diptera: Agromyzidae). Fla Entomol 49: 50-80.

VAN LENTEREN JC, HEMERIK L, LINS JC AND BUENO VH. 2016. Functional responses of three neotropical mirid predators to eggs of Tuta absoluta on tomato. Insects 7: $1-10$.

WHEELER AG. 2000. Predacious plant bugs (Miridae). In: Schaefer CW and Panizzi AR (Eds), Heteroptera of economic importance. CRC Press: Boca Raton, p. $657-$ 693.

WHEELER AG. 2001. Biology of the Plant Bugs (Hemiptera: Miridae). Pests, predators, opportunists. Cornell University Press: Ithaca, New York, $507 \mathrm{p}$.

WHEELER QD AND WHEELER AG. 1994. Mycophagous Miridae? Associations of Cylapinae (Heteroptera) with Pyrenomycete Fungi (Euascomycetes: Xylariaceae). J New York Entomol S 102: 114-117.

YÉPEZ FF, CLAVIJO J AND ROMERO I. 1990. Espécies del complejo Heliothis virescens (Fabricius, 1781) (Lepidoptera: Noctuidae) y sus plantas hospederas em Venezuela. Revista da Faculdade de Agronomia 16: 169175.

ZAWADNEAK MAC, GONÇALVES RB, PIMENTEL IC, SCHUBER JM, SANTOS B, POLTRONIERI AS AND SOLIS MA. 2016. First record of Duponchelia fovealis (Lepidoptera: Crambidae) in South America. Idesia (Arica) 34: 91-95. 